\title{
СИНТЕЗ ДВОКОНТУРНОЇ АВТОМАТИЧНОЇ СИСТЕМИ РЕГУЛЮВАННЯ 3 ДИФЕРЕНЦІЮВАННЯМ СИГНАЛУ 3 ПРОМІЖНОЇ ТОЧКИ
}

\author{
Новіков П. В. ${ }^{1}$, Штіфзон О. Й. ${ }^{2}$, Шило Я. А. ${ }^{3}$ \\ 1,2,3 Національний технічний університет України "Київський політехнічний інститут імені Ігоря Сікорського"; м. Київ, \\ пр. Перемоги, 37 \\ ORCID: ${ }^{1}$ http://orcid.org/0000-0002-2790-5809, ${ }^{2}$ http://orcid.org/0000-0003-0011-4617 \\ E-mail: ${ }^{1}$ p.novikov@kpi.ua, ${ }^{2}$ oshtifzon@gmail.com, ${ }^{3}$ yaroslava.ana@gmail.com
}

Copyright (C) 2021 by author and the journal “Automation of technological and business - processes”.

This work is licensed under the Creative Commons Attribution International License (CC BY).

http://creativecommons.org/licanses/by/4.0

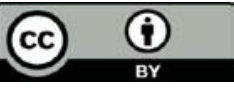

ONAFT

Open Access

DOI:

Анотація: У статті розглянуто застосування сучасної методики налаштування двоконтурних автоматичних систем регулювання (ДАСР) з введенням диференціатора в проміжній точц̧і. Мета статті полягає в аналізі існуючих методик налаштування ДАСР, дослідженні сучасної методики налаштування на прикладі теплоенергетичного об'єкта, а також порівнянні ї̈ з класичною методикою. На основі проведеного аналізу для налаштування системи регулювання температурного режиму прямоточного котлоагрегату обрано методику, запропоновану Свириденко В.П. Проведено процедуру ідентифікаиії контурів регулювання. Отримано моделі температурних контурів вода-парового тракту пиловугільного прямоточного котлоагрегату, наведено перехідні характеристики інериійної і проміжної ділянок. Здійснено розрахунок ДАСР за класичною методикою, а також для порівняння розрахована одноконтурана система регулювання. Результати комп'ютерного моделювання системи регулювання температурного режиму водо-парового тракту свідчать, щзо класична методика налаштування диференціатора не забезпечує необхідної якості перехідних процесів, наявна велика коливальність, щзо не допустимо для даного теплоенергетичного об'єкту. Для иъього ж об'єкта проведений розрахунок за методикою Свириденка В.П. Отримані перехідні процеси мають більший ступінь затухання в середньому на 30\%. За результатами дослідження можна зробити висновок, що запропонована методика налаштування ДАСР в порівнянні з класичною методикою краше підходить для налаштування об 'єктів, до яких відносяться прямоточні котлоагрегати. Розглянута методика є відносно простою з точки зору ї̈ використання, має чітко сформульовані критерії та підкріплена повним набором розрахункових формул. Визначено недоліки даної методики і наведені рекомендації для ї̈ подальшого удосконалення.

Abstract: The article considers the application of modern methods of setting up double-loop feedback control system with the introduction of a differentiator at an intermediate point (DACS). The purpose of the article is to analyze the existing methods of setting up the DACS, to study the modern methods of setting up on the example of a thermal power plant, as well as to compare it with the classical method. On the basis of the conducted analysis for tuning of system of regulation of a temperature mode of the direct-flow boiler unit the technique offered by V. Sviridenko is chosen. The procedure of identification of control loops is carried out. Models of temperature contours of the water-steam path of the direct-flow coalfired boiler unit are obtained, the transient characteristics of the inertial and intermediate sections are given. DACS was calculated according to the classical method, and a single-circuit control system was calculated for comparison. The results of computer simulation of the temperature control system of the water and steam tract show that the classical method of tune the differentiator does not provide the required quality of transients, there is a large fluctuation, which is unacceptable for this heat plant. For the same plant, the calculation was performed according to the method of V. Svyridenko. The obtained transients have a greater degree of attenuation by an average of 30\%. According to the results of the study, it can be concluded that the proposed method of setting the DACS in comparison with the classical method is better suited for setting up plants, which include direct-flow boilers. The considered technique is relatively simple from the point of view of its use, has clearly formulated criteria and is supported by a full set of calculation formulas. The shortcomings of this technique are identified and recommendations for its further improvement are given.

Ключові слова: двоконтурна схема, диференціатор, методика налаштування, система керування.

Key words: double-loop scheme, differentiator, tuning method, control system.

Вступ.

Двоконтурні автоматичні системи регулювання з диференціюванням сигналу з проміжної точки (ДАСР) широко 
застосовуються в тепловій енергетиці в САР первинної і вторинної пари, в регуляторах, що корегують співвідношення живильна вода-паливо, які забезпечують необхідний температурний режим по водо-паровому тракту котла до першого регульованого впорскування, в регуляторах потужності енергоблоку і тиску пари перед турбіною [1].

Однією з головних задач при проектуванні, налагодженні та експлуатації САР є вибір оптимальних параметрів налаштування системи, що забезпечують необхідну якість регулювання в широкому діапазоні зміни навантажень. Отримання оптимальних значень можливе при наявності динамічних характеристик об'єктів регулювання [2].

Для налаштування ДАСР існує набір різних методик налаштування [1], але однозначно спільним для усіх методик $\epsilon$ той факт, що первинним для будь-якої ДАСР є точне визначення параметрів диференціатора. Від цього будуть залежати налаштування регулятора, а від так і загальна якість перехідних процесів в системі. Таким чином актуально $\epsilon$ задача дослідження існуючих методик налаштування ДАСР і визначення оптимальної для налаштування САР температурного режиму прямоточного котлоагретата ТПП-210А, який виступає як об'єкт керування в даному дослідженні.

\section{Аналіз літературних даних і постановка проблеми}

Для покращення якості регулювання, а також для пришвидшення реакції системи регулювання на вплив збурення при керуванні інерційними об'єктами використовують схеми з введенням диференціатора в проміжній точці (ДАСР). На рис. 01 наведена типова структурна схема такої САР: $r$ - завдання, $d$ - збурення, $y$ - вихідна величина, що регулюється, $W_{P}(s)$ - передавальна функція регулятора, $W_{д}(s)$ - передавальна функція диференціатора, $W^{I H}{ }_{о 5}(s)-$ передавальна функція інерційного об'єкта керування, $W^{\Pi P}{ }_{\text {оБ}}(s)$ - передавальна функція проміжної ділянки об'єкта керування.

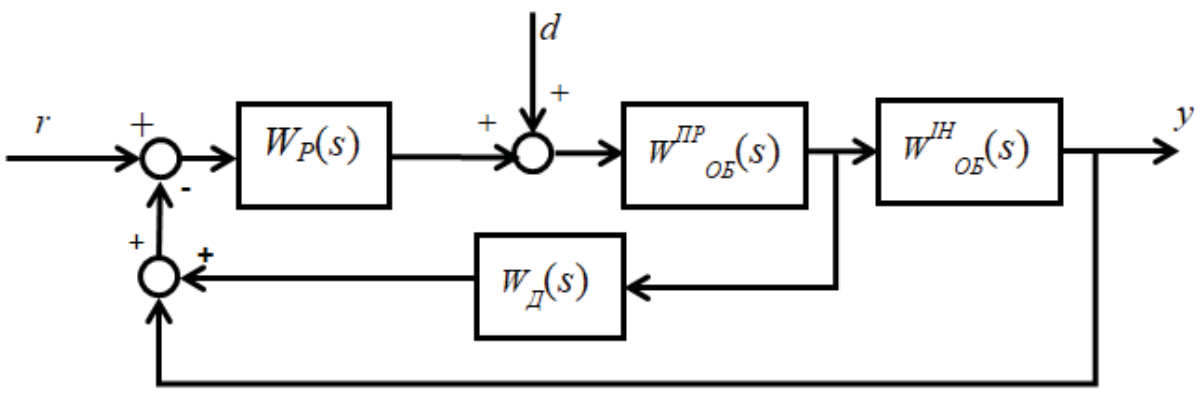

Рис. 1 - Структурна схема ДАСР

Для ДАСР існує безліч варіантів параметрів налаштувань із заданою мірою загасання перехідних процесів, але вони відрізняються динамічними відхиленнями і часом перехідних процесів регульованих параметрів [1].

Питання вдосконалення і оптимізації методик налаштування ДАСР для об'єктів теплоенергетики вирішувалися в роботах В.Я. Ротача[3], С.П. Стефані [4], Г.Т. Кулакова [2], В.П. Свириденка [1], В.А. Біленко [5, 6], В.В. Жигунова, I.А. Шавочкіна [7].

При налаштуванні ДАСР визначальним для якості перехідних процесів є правильний вибір параметрів налаштування диференціатора $\left(T_{\partial}\right.$ і $\left.K_{\partial}\right)$ за сигналом проміжної ділянки, але з урахуванням динамічних характеристик основного сигналу.

Вибір методики визначення налаштувань диференціатора істотно впливає на якість регулювання. Традиційний розрахунок налаштувань диференціатора типової ДАСР базується на припущенні про можливість розрахунку одного контуру незалежно від іншого [4]. При цьому налаштування диференціатора обчислюють за динамічними характеристиками інерційного ділянки, входом якого є проміжна регульована величина, а виходом - основна регульована величина. Після визначення налаштувань диференціатора переходять до розрахунку налаштувань основного регулятора [2].

Первинність визначення налаштувань диференціатора підтверджується і методикою налаштування диференціатора котельного регулятора тиску в схемі САУП-2 регулятори потужності і тиску пари перед турбіною [5].

Для усунення похибок при ідентифікації інерційної та проміжної ділянок в [2] пропонується проводити розрахунок налаштувань диференціатора грунтуючись на розімкнуто-замкнутій системі керування (РЗС): розімкненій по основній регульованій величині і замкненій по проміжній величині. При цьому стрибкоподібна зміна завдання на вході одноконтурної швидкодіючої системи (регулятор - проміжна ділянка) забезпечує, при відповідному виборі налаштувань регулятора, такі зміни проміжної регульованої величини, які коливаються навколо віртуального високочастотного сигналу на вході в інерційну ділянку об'єкта регулювання. Так як швидкодіючі коливання внутрішнього контуру РЗС не пропускаються інерційним ділянкою, розрахунок налаштувань диференціатора здійснюється по передавальній функції інерційної ділянки [8].

Сучасніші методики [5] використовують диференціатори більш високого порядку із застосуванням моделей, які реалізовуються аперіодичними ланками від 2-го до 7-го порядку, що можливо здійснити тільки на мікропроцесорній техніці із залученням висококваліфікованого налагоджувального персоналу.

В [7] приведені емпіричні формули для визначення $K_{\partial}$ i $T_{\partial}$ диференціатора. Як видно 3 [7] за усередненими параметрами при незначній зміні $K_{\partial}$, постійна часу диференціатора $T_{\partial}$ має істотно менше значення в порівнянні 3 
параметрами, визначеними при збуренні по каналу регулюючої дії. При цьому зміни перехідних процесів при збуренні по каналу регулюючої дії не значні.

В статті [1] сформульовані критерії для вибору оптимальних параметрів налаштування диференціатора $T_{\partial}$ i $K_{\partial}$.

№1. Критерієм для визначення оптимального значення $T_{\partial}$ при стрибкоподібному збуренні по каналу регулюючої дії має бути поєднання виходу диференційованого сигналу проміжної ділянки на нульове значення у момент виходу основного сигналу в усталений режим.

№2. Враховуючи вплив зміни параметрів налаштування диференціатора на якість перехідних процесів, цей спосіб розрахунку налаштувань ДАСР передбачає формування монотонного сигналу на вхід регулятора із заздалегідь заданою мірою загасання при вибраному співвідношенні $\tau /$ Та по кривій розгону $W_{E K B}(s)$ :

$$
W_{E К в}(s)=W_{\Pi Р}(s) W_{I H}(s)+W_{\Pi Р}(s) W_{\text {диФ }}(s)
$$

У цьому способі розрахунку налаштувань ДАСР вибрано співвідношенні $\tau / T=0.1$, де забезпечується максимальний коефіцієнт підсилення регулятора, а також реальній можливості реалізації і використання існуючих номограм для визначення оптимальних параметрів налаштування ПІ-регуляторів статичних об'єктів, коли динаміка об'єкту може бути апроксимована аперіодичною ланкою першого порядку із запізнюванням, а також номограм Львів ОРГРЕС для об'єктів, апроксимованих ланками 1-го, 2-го, 3-го і 4-го порядку із запізнюванням і 30\%-вим перерегулюванням по регулюючому органу [1].

№3. За оптимальну криву розгону $W_{\text {опт }}(s)$, до якої повинна прагнути в часовому діапазоні $W_{E K B}(s)$ з урахуванням динамічних характеристик проміжної ділянки і інерційного сигналу приймається аперіодична ланка першого порядку

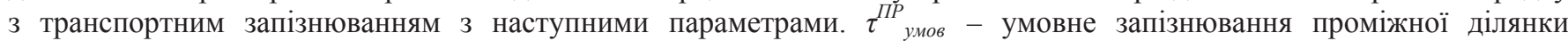
визначається за відомим методом проведенням дотичної через точку перегину кривої розгону $W_{\text {OПт }}(s), T=10 \tau($ iз співвідношення $\tau / T=0.1), K_{O п T}=K_{I H}$ (коефіцієнт підсилення інерційної ділянки).

Для визначення $K_{\partial}$ i $T_{\partial}$ за методикою [1] наведені аналітичні формули, які отримані на основі аналізу амплітуднофазових характеристик об'єкту керування. Параметри налаштування регулятора $\left(K_{P}\right.$ i $\left.T_{i}\right)$ визначаються 3 використанням розрахункових параметрів диференціатора $\left(K_{\partial}\right.$ i $\left.T_{\partial}\right)$ будь-яким з відомих методів за амплітуднофазовою характеристикою.

Підсумовуючи вище проведений огляд можна стверджувати, що існуючі методики розрахунку параметрів налаштувань ДАСР не є універсальними, вони розроблені для певного співвідношення інерційностей проміжної і інерційної ділянок, в окремих методиках використовуються емпіричні формули для розрахунку параметрів, але в цьому випадку отримані в результаті параметри не $є$ оптимальними. Інші методики характеризуються складністю застосування. Методика [1] є відносно простою з точки зору ії використання, має чітко сформульовані критерії та підкріплена повним набором розрахункових формул.

\section{Ідентифікація ділянок водо-парового тракту}

Підвищити якість регулювання температури перегрітої пари можна за рахунок зменшення похибки при апроксимації експериментальних перехідних характеристик проміжної і інерційної ділянок об'єкта регулювання [2]

У даній роботі як основний сигнал, що регулюється, розглядається температура перегрітої пари після екрану поворотної камери (ПЕ) котлоагрегату ТПП-210А. Усереднена перехідна характеристика об'єкта керування наведена на рис. 2.

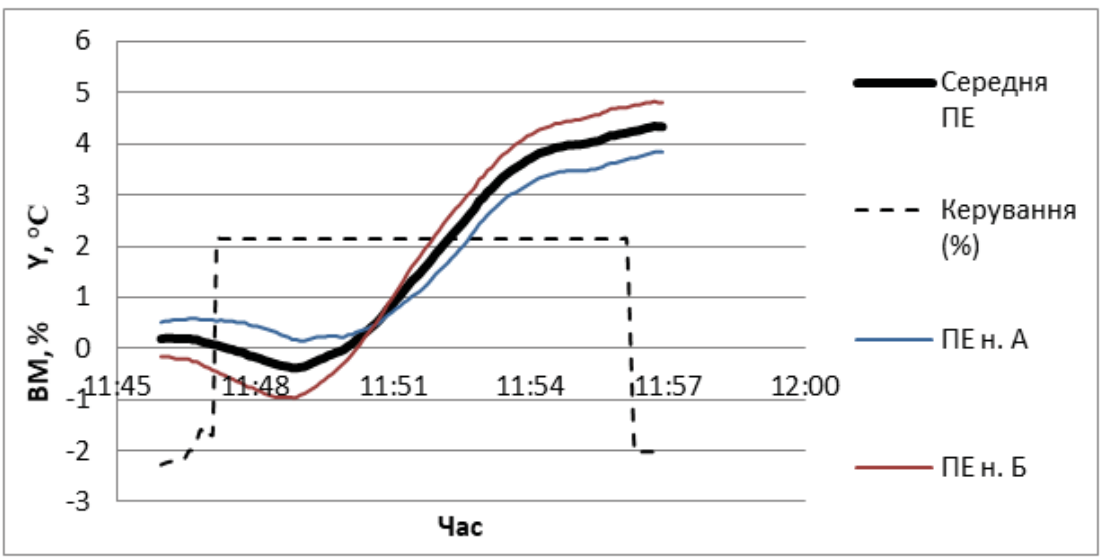

ПЕ н. А, ПЕ н. Б - температури по ниткам А і Б відповідно

Рис. 2 - Усереднена перехідна характеристика об'скта

Ідентифікацію об’єкта керування проведено за допомогою методу додаткових членів [9]. Перевагою цього методу $€$ те, що крім сталих часу об’єкта можна визначити також порядок диференційного рівняння $n$.

В загальному випадку модель об’єкта має вигляд:

$$
W_{O Б}(s)=\frac{K_{O Б} e^{-\tau_{O Б} s}}{\left(T_{1} s+1\right)\left(T_{2} s+1\right) \ldots\left(T_{n} s+1\right)}
$$




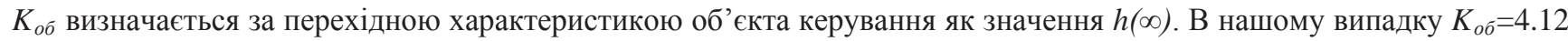
${ }^{\circ} \mathrm{C} / \%$.

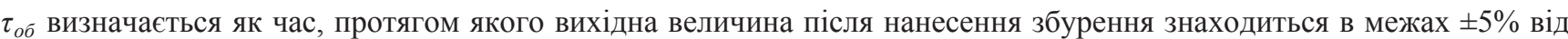
сталого значення. В нашому випадку $\tau_{o \sigma}=90 \mathrm{c}$.

Чисте транспортне запізнювання за каналом ПЕ складає $\tau_{\Pi п \Pi}=90$ c, $\mathrm{t}_{1}=254-94=160$ (c), $\mathrm{t}_{2}=160 / 2+94=174$ (c), $\mathrm{h}\left(\mathrm{t}_{2}\right)=0,305$. Згідно [8] порядок диференційного рівняння, що описує динаміку даного контуру, становить $\mathrm{n}=2$. $\mathrm{D}_{\mathrm{n}}=0,642, \mathrm{~T}_{1}=103, \mathrm{~T}_{2}=51$.

Остаточно модель об'єкта керування буде мати вигляд:

$$
W_{\text {IIE }}(s)=\frac{4.12 e^{-90 s}}{(103 s+1)(51 s+1)}
$$

Похибка апроксимації для моделі температури ПЕ складає 3,9\%.

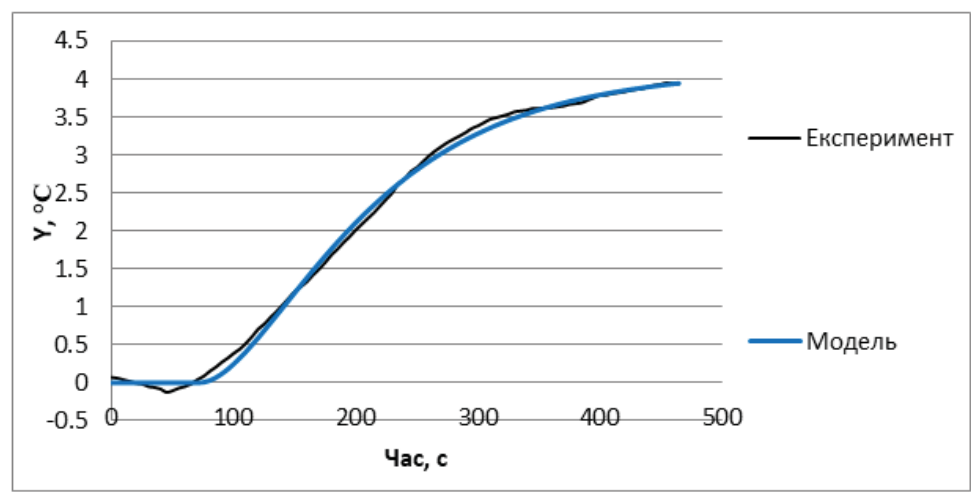

Рис. 3 - Порівняння моделі з експериментальними даними

Аналогічним чином розрахована функція передачі для каналу температури за ВРЧ:

$$
W_{B P Y}(s)=\frac{2.88 e^{-15 s}}{(79 s+1)(39 s+1)}
$$

\section{Розрахунок налаштувань ДАСР за класичною методикою}

Схема на рис. 1 може застосовуватись, коли відомі окремо функції передачі $W^{I P}$ оБ$(s)$ і $W^{I H}$ оБ$(s)$. Водо-паровий тракт прямоточного котлоагрегату представляє собою набір теплообмінників, які включені послідовно один за одним (рис. 4). Екран поворотної камери (ПЕ) розташований за ділянкою ВРЧ і між ними відсутня регулююча апаратура. Для цих двох сигналів керуючий вплив є спільним - для САР температурного режиму це зміна витрати палива. Тому при ідентифікації ділянок водо-парового тракту прямоточного котлоагрегату на основі розгінних характеристик виходить, що $W^{I H}{ }_{O 5}(s)$ враховує динамічні властивості ділянки $W^{I P}{ }_{\text {оБ }}(s)$. Відповідно для нашого випадку схема на рис. 1 повинна змінитися (рис. 5).

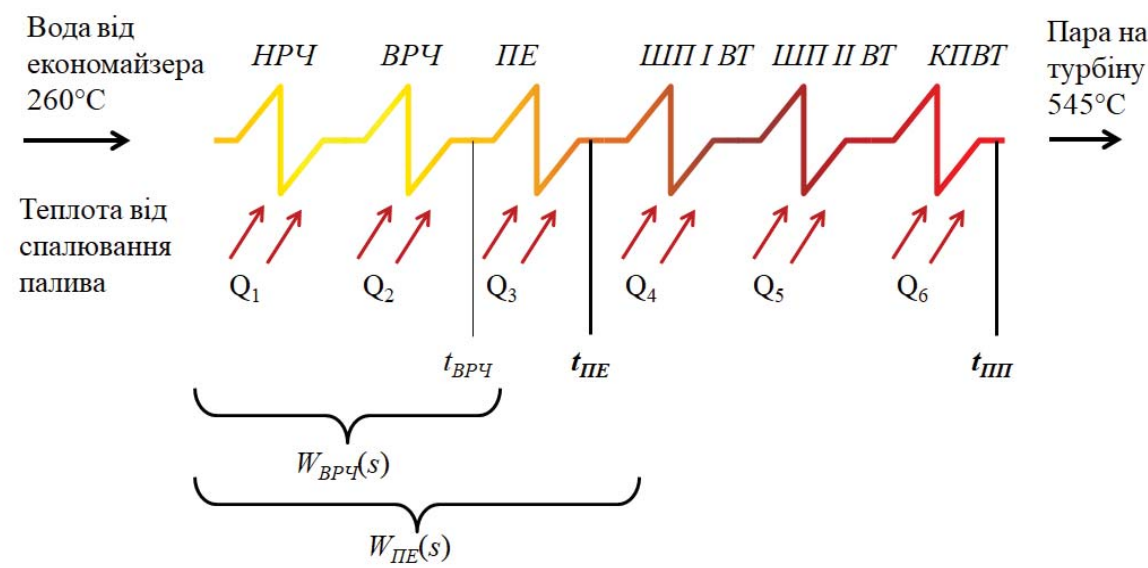

ШП I ВТ, ШП II ВТ - screen high pressure heaters I and II, КПВT - convective high pressure heater, $t_{\Pi \Pi}-$ temperature of superheated steam

Рис. 4 - Розташування теплообмінників по водо-паровому тракту в прямоточному котлоагрегаті ТПП-210А 


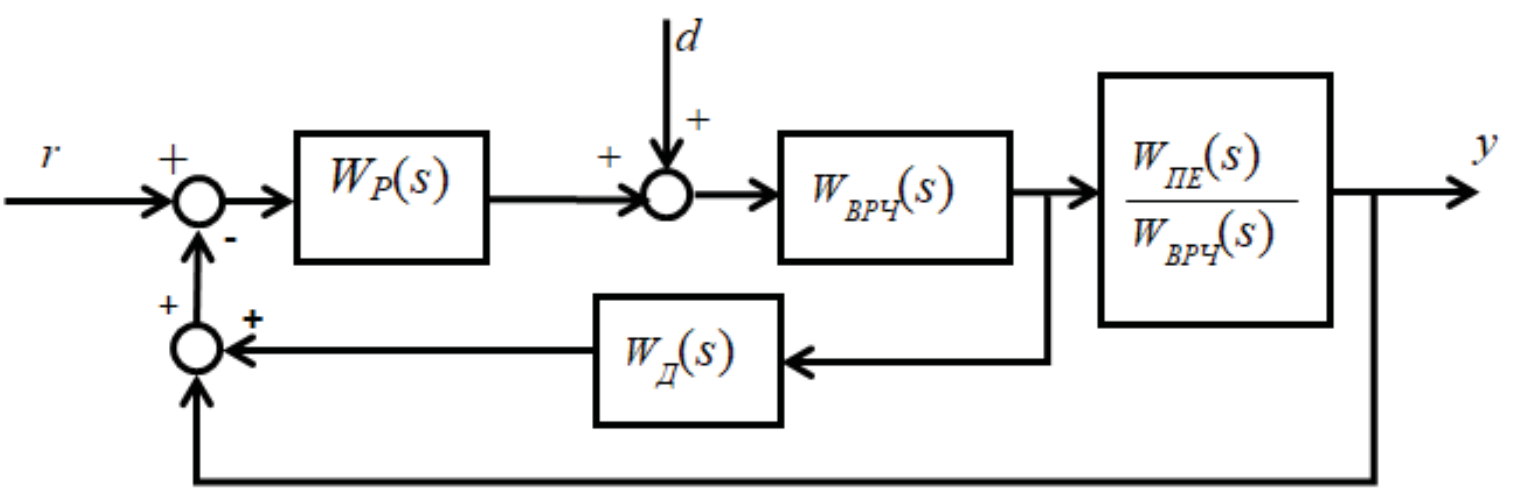

Рис. 5 - Приведена схема ДАСР для ділянки водо-парового тракту

Функція передачі ділянки ВРЧ-ПЕ буде мати вигляд:

$$
W_{B P Y-\Pi E}(s)=\frac{W_{\Pi E}(s)}{W_{B P Y}(s)}=\frac{4.12(79 s+1)(39 s+1) e^{-90 s}}{2.88(103 s+1)(51 s+1) e^{-15 s}}=1.43 \frac{(79 s+1)(39 s+1)}{(103 s+1)(51 s+1)} e^{-75 s}
$$

Саме функцію передачі (5) при розрахунку налаштувань ДАСР ми в подальшому будемо розглядати як інерційний об'єкт.

Згідно класичної методики параметри диференціатора будемо брати як обернені параметрам ПІ-регулятора, що синтезується для ділянки ПЕ. Параметри ПІ-регулятора для ділянки ПЕ розраховані за методом РАФХ на кореневий критерій якості $m=0.485$, що приблизно відповідає коефіцієнту затухання перехідного процесу $\psi=0.95$.

$$
W_{\text {Д }}^{B P \Psi}=\frac{2.44 \cdot 35 s}{35 s+1}=\frac{85.4 s}{35 s+1}
$$

На рис. 6 наведене порівняння реакції об’єкта керування на одиничне ступінчате збурення з урахуванням сигналу від диференціатора.

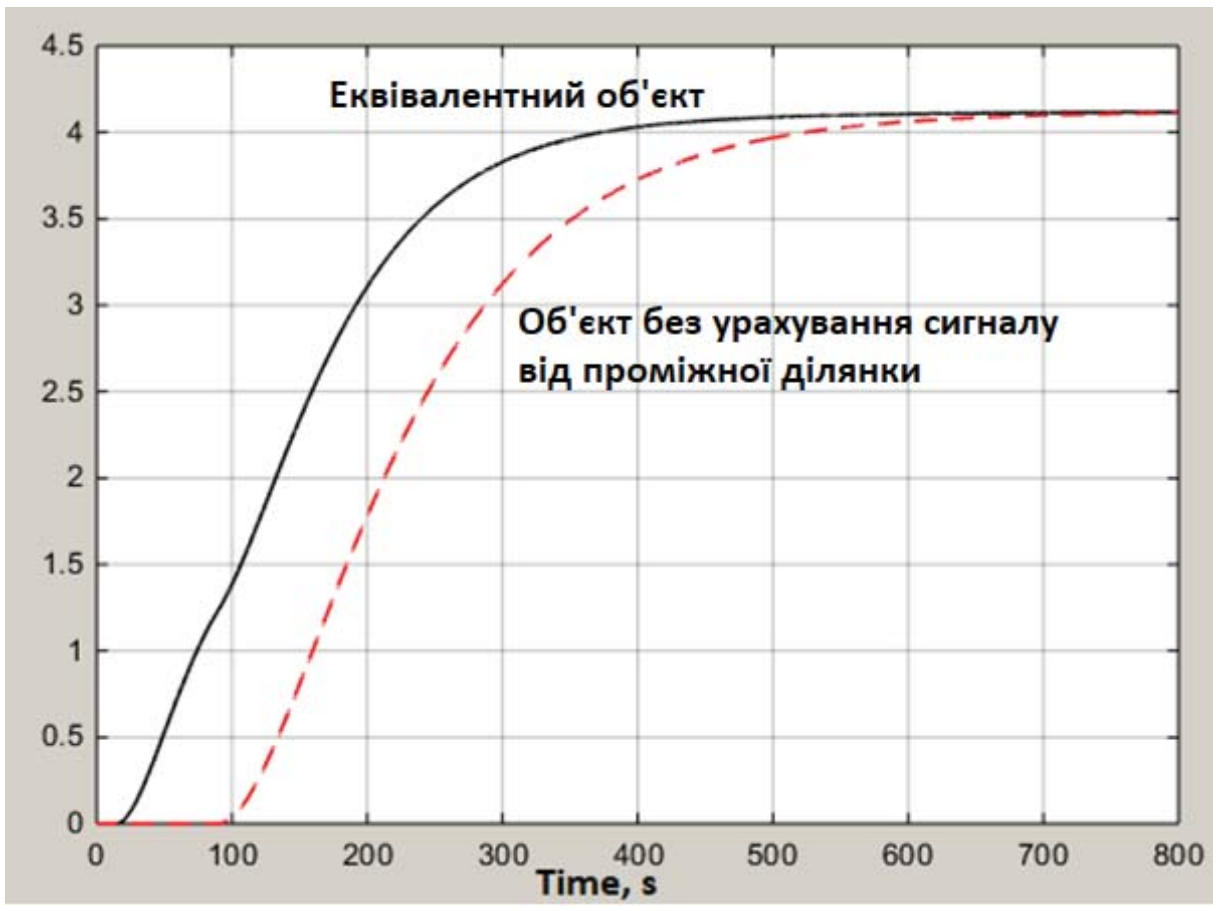

Рис. 6 - Порівняння перехідних характеристик еквівалентного і інерційного об'сктів

При стрибкоподібному збуренні по каналу регулюючої дії на вхід регулятора надходить сигнал $W_{E \kappa B}(s)$ небалансу суми основного сигналу у і сигналу завдання $r$, а також диференційований сигнал проміжної ділянки, що володіє значно кращими динамічними властивостями в порівнянні з основним сигналом. За цим еквівалентним об'єктом визначаються параметри налаштування регулятора ( $K_{P}$ i $T_{i}$ для ПІ-регулятора). Отримані наступні налаштування ПІрегулятора: $K_{P}=0.96, T_{i}=240 \mathrm{c}$. 


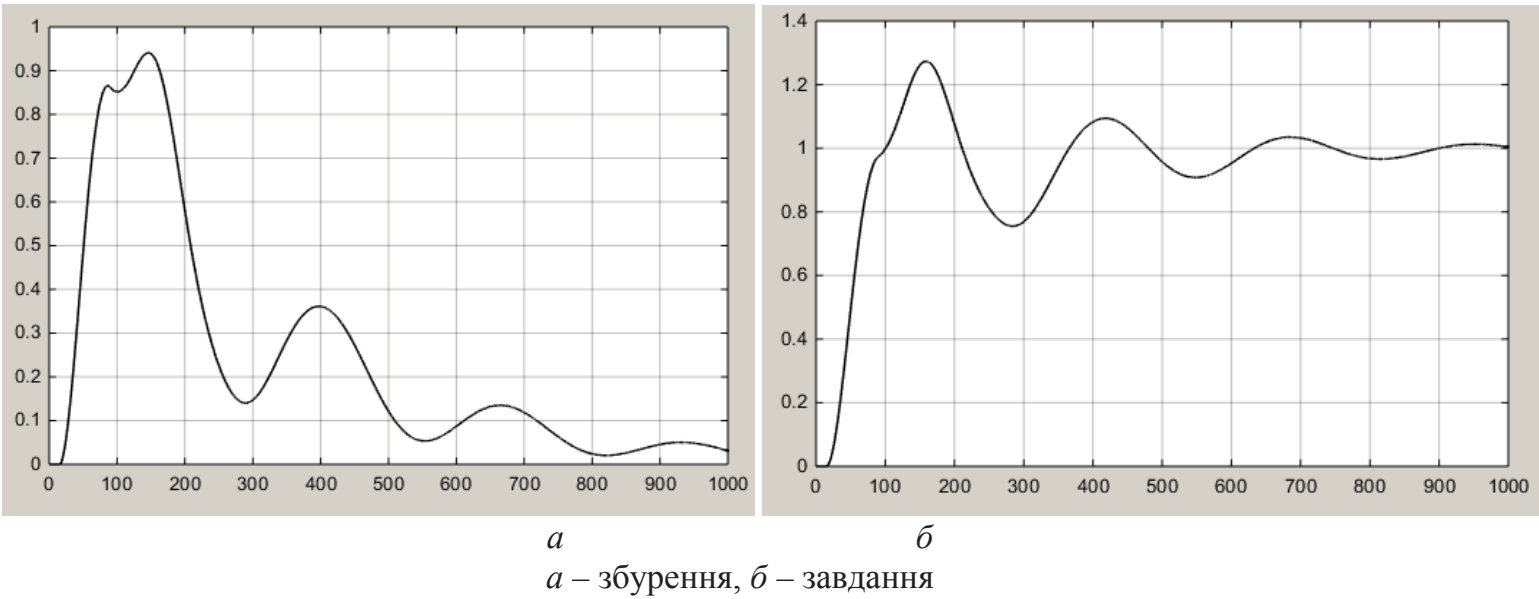

Рис. 7 - Перехідні процеси ДАСР

Порівняємо отриману двоконтурну систему з одноконтурною системою керування. Параметри ПІ-регулятора для одноконтурної системи керування розраховані за методом РАФХ на кореневий критерій якості $m=0.485$, що приблизно відповідає коефіцієнту затухання перехідного процесу $\psi=0.95$. Об'єктом для розрахунку виступає функція передачі за каналом ПЕ (3). Отримані параметри ПІ-регулятора $K_{P}=0.174, K_{i}=0.00117, T_{i}=149$. На рис. 7 наведене порівняння перехідних процесів системи $з$ диференціатором і одноконтурної системи.

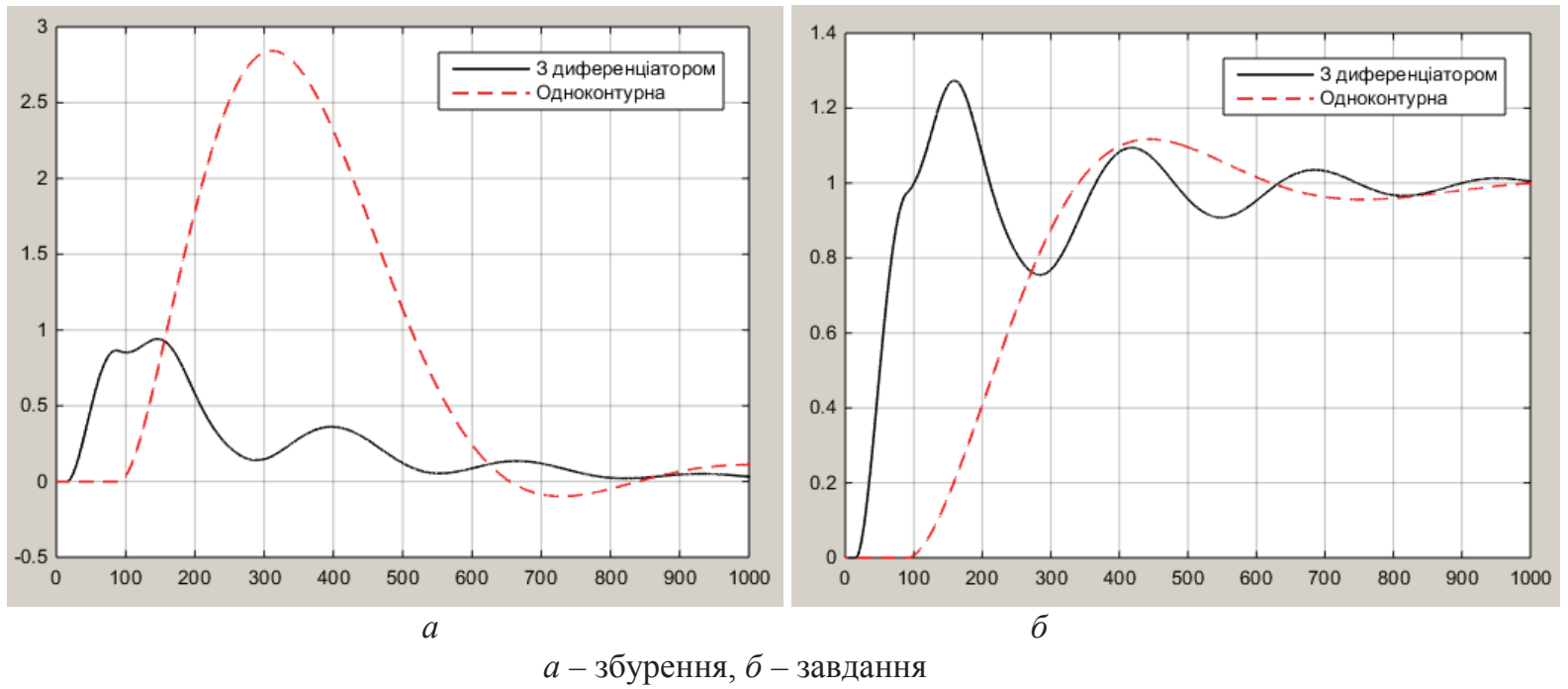

Рис. 8 - Порівняння перехідних процесів

За результатами комп’ютерного моделювання контуру температурного режиму пароводяного тракту можна зробити висновок, що класична методика налаштування диференціатора не забезпечує необхідної якості перехідних процесів, наявна велика коливальність перехідних процесів, що не допустимо для даного теплоенергетичного об’єкту керування. Перехідні процеси в одноконтурній системі мають аперіодичний характер, але в них наявна динамічна похибка по каналу регулюючої дії, що 2.8 рази більша в порівнянні з ДАСР. Очевидно, що ні одноконтурна схема, ні ДАСР, розрахована за класичною методикою, не забезпечують задовільних параметрів.

\section{Розрахунку налаштувань ДАСР за сучасною методикою}

Скористаємося методикою розрахунку параметрів ДАСР, запропонованою Свириденко В.П. [1]. Розрахунок параметрів ДАСР здійснюється в низькочастотній області при частоті $\omega^{*}=0,005$ рад/сек.

Для функції передачі головної ділянки (3) модуль $M_{\Pi Е}$ і фаза $\varphi_{\Pi Е}$ об’єкта $W_{\Pi E}(s)$ при частоті $\omega^{*}$ :

$M_{\Pi E}\left(\omega^{*}\right)=3.55$

$\varphi_{\Pi E}\left(\omega^{*}\right)=-67.3^{\circ}$

Для функції передачі проміжної ділянки (4) модуль $M_{B P \Psi}$ і фаза $\varphi_{B P \Psi}$ об'єкта $W_{B P ч}(s)$ при частоті $\omega^{*}$ :

$M_{B P Y}\left(\omega^{*}\right)=2.63$

$\varphi_{B P Y}\left(\omega^{*}\right)=-36.9^{\circ}$ 
Визначимо умовне запізнювання проміжної ділянки $\tau_{\text {ммов }}^{\Pi P}$ проведенням дотичної через точку перегину кривої розгону $W_{B P 4}(s)$.

$\tau_{\text {умов }}^{\Pi P}=18 c$

Тоді функція передачі умовної оптимальної кривої розгону $W_{\text {опт }}(s)$, до якої повинна прагнути в часовому діапазоні $W_{E K B}(s)$ буде мати вигляд:

$$
W_{\text {OПT }}(s)=\frac{4.12 e^{-18 s}}{(180 s+1)}
$$

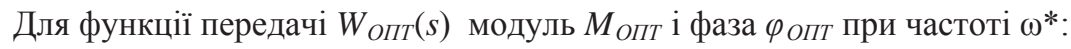

$M_{\text {OПT }}\left(\omega^{*}\right)=3.06$

$\varphi_{\text {OПT }}(\omega=0.01)=-47.1^{\circ}$

Згідно [1] визначається постійна часу диференціатора :

Для збурення по каналу регулюючої дії:

$$
T_{\text {д }}=\frac{\operatorname{tg}\left(\varphi_{\Pi E}-\varphi_{\text {OП }}\right)}{0.005}=\frac{\operatorname{tg}(-67.3+36.9)}{0.005}=117.6 \mathrm{c}
$$

Модуль АФХ одиничної передатної функції диференціатора при збуренні по каналу регулюючої дії:

$$
M_{\text {д }}^{\text {одн }}(\omega=0.01)=\frac{T_{\text {д }} \omega}{\sqrt{T_{\text {д }}^{2} \omega^{2}+1}}=\frac{117.6 \cdot 0.005}{\sqrt{117.6^{2} \cdot 0.005^{2}+1}}=0.507
$$

Кут різниці фаз фазочастотної характеристики $W_{\text {ОПт }}(s)$ i $W_{\text {ПЕ }}(s)$ в градусах:

$$
\alpha=67.3^{\circ}-47.1^{\circ}=20.2^{\circ}
$$

Визначаємо модуль чисельника формули розрахунку $K_{\partial}$ :

$$
\begin{aligned}
& M_{\text {OПT }}\left(\omega^{*}\right)-M_{\text {ПIE }}\left(\omega^{*}\right)=
\end{aligned}
$$

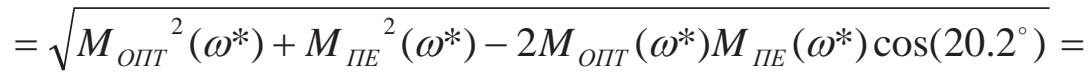

$$
\begin{aligned}
& =\sqrt{3.06^{2}+3.55^{2}-2 \times 3.06 \times 3.55 \times 0.9385}=1.254
\end{aligned}
$$

Визначаємо коефіцієнт посилення диференціатора Кд при збуренні по каналу регулюючої дії

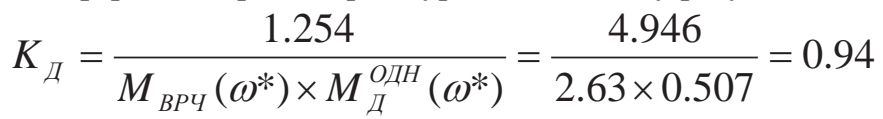

За оптимальні параметри налаштування диференціатора беруться:

$K_{\partial}=0.94$

$T_{\partial}=118 \mathrm{c}$

Параметри ПІ-регулятора визначаються за методом РАФХ на кореневий критерій якості $m=0.366$, що приблизно відповідає коефіцієнту затухання перехідного процесу $\psi=0.75$. Об’єктом для розрахунку виступає функція передачі (7).

Отримані наступні налаштування ПІ-регулятора: $K_{P}=0.25, T_{i}=119$.

Перехідні процеси в розрахованій ДАСР приведені на рис. 9 при збуреннях по каналах регулюючої дії і завдання.
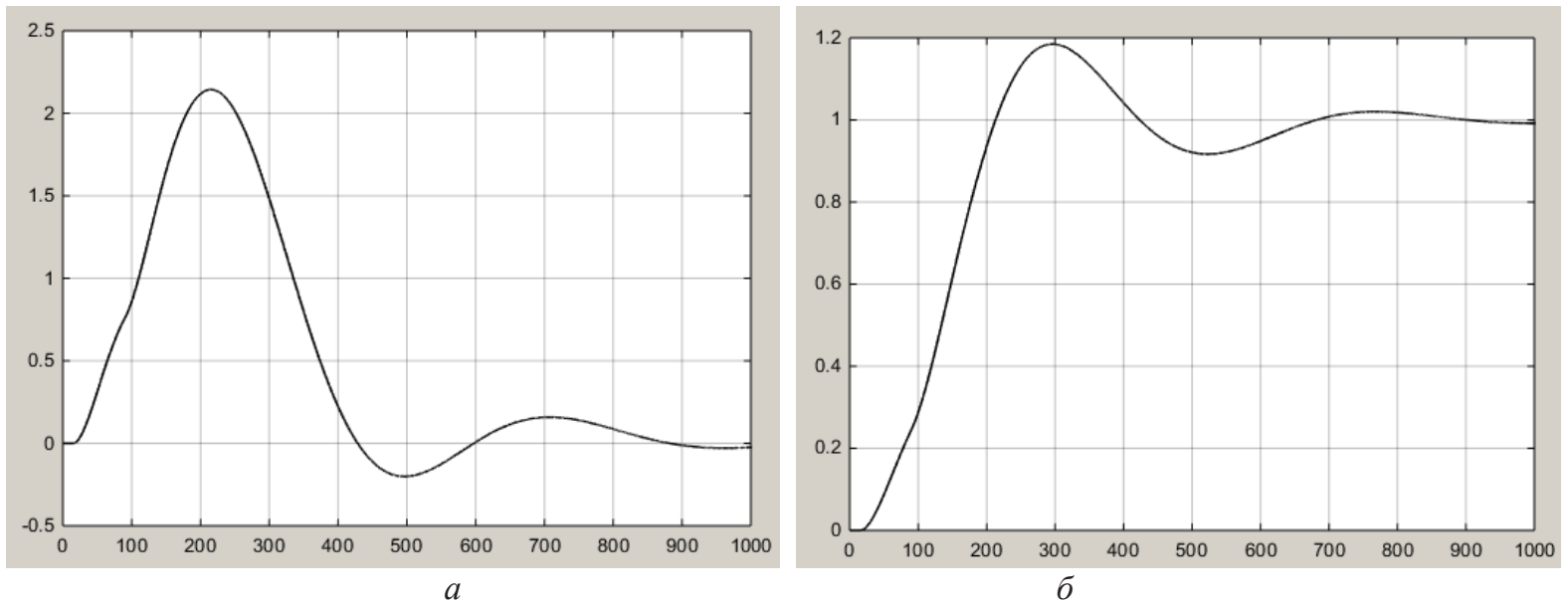

$a-$ збурення, $\sigma$ - завдання

Рис. 9 - Перехідні процеси ДАСР 

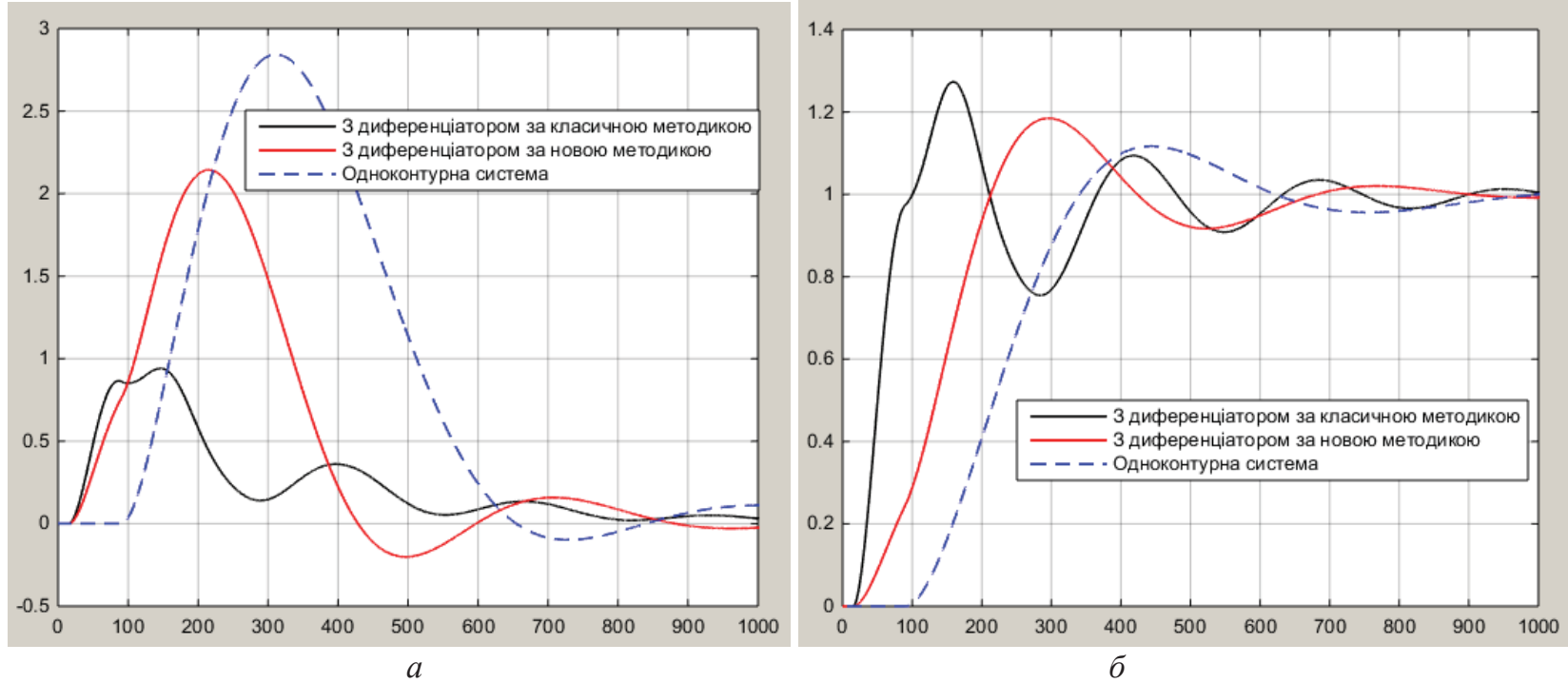

$a-$ збурення, $\sigma$ - завдання

Рис. 10 - Порівняння перехідних процесів

В таблиці 1 наведені прямі показники якості перехідних процесів.

Таблиця 1 - Прямі показники якості перехідних процесів для різних схем

\begin{tabular}{|l|l|l|r|l|r|r|}
\hline \multirow{2}{*}{ Показник } & \multicolumn{3}{|c|}{ Канал «збурення-вихід» } & \multicolumn{3}{|c|}{ Канал «завдання -вихід» } \\
\cline { 2 - 7 } & $\begin{array}{l}\text { ДАСР } \\
\text { класична } \\
\text { методик }\end{array}$ & $\begin{array}{l}\text { ДАСР } \\
\text { методика } \\
\text { Свириденка }\end{array}$ & $\begin{array}{l}\text { Одноконтурна } \\
\text { ДАСР } \\
\text { класична } \\
\text { методик }\end{array}$ & $\begin{array}{l}\text { ДАСР методика } \\
\text { Свириденка }\end{array}$ & Одноконтурна \\
\hline$\Delta_{\text {д }},{ }^{\circ} \mathrm{C}$ & 0,94 & 2,14 & 2,84 & 0,3 & 0,18 & $18 \%$ \\
\hline$\delta, \%$ & $0 \%$ & $9,35 \%$ & $3,5 \%$ & $30 \%$ & 0,89 & $10 \%$ \\
\hline$\psi,-$ & 0,62 & \multicolumn{2}{|c|}{0,93} & 0,96 & 0,67 & \\
\hline
\end{tabular}

Висновки

На відміну від одноконтурних систем, кількість методик налаштування двоконтурних систем є набагато меншою. Це пояснюється складністю даних схем через взаємний вплив контурів регулювання та більшу кількість параметрів налаштування. Для схем 3 введенням диференціатора в проміжній точні проведено аналіз існуючих методик налаштування. Всі методики відзначають необхідність первинності налаштування параметрів диференціатора. Відносно нова методика, запропонована фахівцями НПО Радій, демонструє кращі результати порівняно 3 класичним підходом, що зазвичай використовується. Варто відзначити, що розглянута методика є відносно простою з точки зору ii використання, має чітко сформульовані критерії та підкріплена повним набором розрахункових формул. До недоліків методики налаштування ДАСР слід віднести неоднозначність вибору частоти, при якій проводяться розрахунки параметрів налаштування диференціатора. Є лише загальна рекомендація, що це має бути інфранизька частота, але грунтовних формул, які б базувалися на частотних характеристиках об'єкта керування, не наведено. Розробка таких рекомендацій є основою для подальших досліджень і удосконалення методики налаштування ДАСР.

\section{Список використаних джерел:}

[1] Свириденко В. П. Способ настройки двухконтурной автоматической системы регулирования (ДАСР) с дифференциатором по опережающему сигналу / В. П. Свириденко // Енергетика та електрифікація.- 2018.-№3.C. 27-37.

[2] Кулаков Г.Т. Комплексная методика оптимизации параметров динамической настройки регуляторов впрысков / Г.Т. Кулаков, М.Л. Горелышева // Энергетика. Известия высших учебных заведений и энергетических объединений СНГ.-2009.- №. 3.-С. 59-66.

[3] Теория автоматического управления: ученик для вузов / В.Я. Ротач.- 5-е изд., перереб. и доп.- М.: Издательский дом МЭИ, 2008.- 396 с., ил.

[4] Стефани Е. П. Основы расчета настройки регуляторов теплоэнергетических процессов [Текст] / Е. П. Стефани М. : Энергия, 1972.- 377 с.

[5] Биленко В.А. Анализ эффективности введения сложных законов преобразования дополнительных сигналов в многоконтурных автоматических системах регулирования энергоблоков [Текст] / В.А. Биленко, И.А. Шавочкин // Теплоэнергетика.- 2006.- № 4.- C. 57-65. https://doi.org/10.1134/S0040601506040082

[6] Биленко В.А. Многоконтурные автоматические системы регулирования с несколькими регулирующими воздействиями и их применение для поддержания температуры пара прямоточных котлов [Текст] / B.A. Биленко // Теплоэнергетика.-2011.-№ 10.- C. 51-59. https://doi.org/10.1134/S004060151110003X 
[7] Жигунов В.В. Повышение эффективности управления мощностью энергоблоков с применением дифференцирования в котельном регуляторе давления пар перед турбиной / В.В. Жигунов, И.А. Шавочкин // Теплоэнергетика.-2011.-№10.-C. 60-69. https://doi.org/10.1134/S0040601511100132

[8] Кулаков, Г. Т. Инженерные экспресс-методы расчета промышленных систем регулирования: спр. пособие / Г. Т. Кулаков. - Минск: Вышэйш. шк., 1984.- 192 с.

[9] Radtke M. Zur Approximation linearer aperiodischer Übergangsfunktionen. Zeitschrift messen, steuern, regeln. 1966. №9. S. 192-196.

[10] Новіков П. В. Автоматизація процесів керування інерційними контурами котлоагрегата теплової електростанції з використанням двоканального нечіткого контролера : дис. ... канд. техн. наук : 05.13 .07 / Національний технічний університет України "Київський політехнічний інститут імені Ігоря Сікорського". Київ, 2019. 191 с.

References:

[1] V. P. Sviridenko,“ Sposob nastroyki dvukhkonturnoy avtomaticheskoy sistemy regulirovaniya (DASR) s differentsiatorom po operezhayushchemu signalu”, Energetics i elektrifikatsiya, No3, $27-37$ (2018).

[2] G. T. Kulakov and M. L. Gorelysheva, "Kompleksnaya metodika optimizatsii parametrov dinamicheskoy nastroykiregulyatorov vpryskov”, Energetika...(Izv. vyssh. ucheb. zavedeniy), No 3, 59-66 (2009).

[3] V.Ya. Rotach, Teoriya avtomaticheskogo upravleniya [Automatic Control Theory], Moskovskiy Energeticheskiy Institut, Moscow, (2008).

[4] E. P. Stefani, Principles for Calculating Regulator Settings for Heat Power Processes, Énergiya, Moscow (1972).

[5] V. A. Bilenko and I. A. Shavochkin, "An Analysis of the Effect of Introducing Complex Laws for Transforming Additional Signals in Multiloop Automatic Control Systems of Power Units”, Teploenergetika, No. 4, 57-65 (2006). https://doi.org/10.1134/S0040601506040082

[6] V.A. Bilenko, "Multi-loop automatic control systems with several control inputs and their application for maintaining steam temperature in once-through boilers”, Teploenergetika, No. 10, 51-59 (2011). https://doi.org/10.1134/S004060151110003X

[7] V.V. Zhigunov and I.A. Shavochkin, "Achieving more efficient control of the power output of power units through the use of differentiation in the boiler controller regulating steam pressure upstream of the turbine”, Teploenergetika, No. 10, 60-69 (2011). https://doi.org/10.1134/S0040601511100132

[8] G. T. Kulakov, Inzhenernyye ekspress-metody rascheta promyshlennykh sistem regulirovaniya, Vysejsaja shkola, Minsk, (1984).

[9] Radtke M. Zur Approximation linearer aperiodischer Übergangsfunktionen. Zeitschrift messen, steuern, regeln. 1966. №9. S. 192-196.

[10] Novikov P. Control processes automation of thermal power plant unit inertial channels using a two-channel fuzzy controller : dissertation ... ph.d.: 05.13.07. National Technical University of Ukraine "Igor Sikorsky Kyiv Polytechnic Institute". Kyiv, 191 p., 2019.

Отримана в редакції 18.01.2021. Прийнята до друку 23.02.2021. Received 18 January 2021. Approved 23 February

2021. Available in Internet 31 March 2021.

\section{УДК 681.181:681.5}

\section{ОГЛЯД СИСТЕМИ РЕГУЛЮВАННЯ РІВНЯ ВОДИ ПАРОГЕНЕРАТОРА БЛОКУ ВВЕР-1000}

\section{Яроцький М. М.}

Одеський національний політехнічний університет, м. Одеса, Україна

E-mail: yarotsky0@gmail.com

Copyright (C 2021 by author and the journal “Automation of technological and business - processes”. This work is licensed under the Creative Commons Attribution International License (CC BY). http://creativecommons.org/licanses/by/4.0

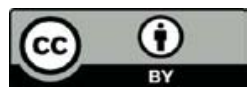

ONAFT

Open Access

DOI:

Анотація. Досліджені властивості парогенератора блоку ВВЕР-1000, виведені основні характеристики об'єкта $і$ вказані основні принципи, які допоможуть застерегти від помилок у вивченні даного питання. Представлені види 